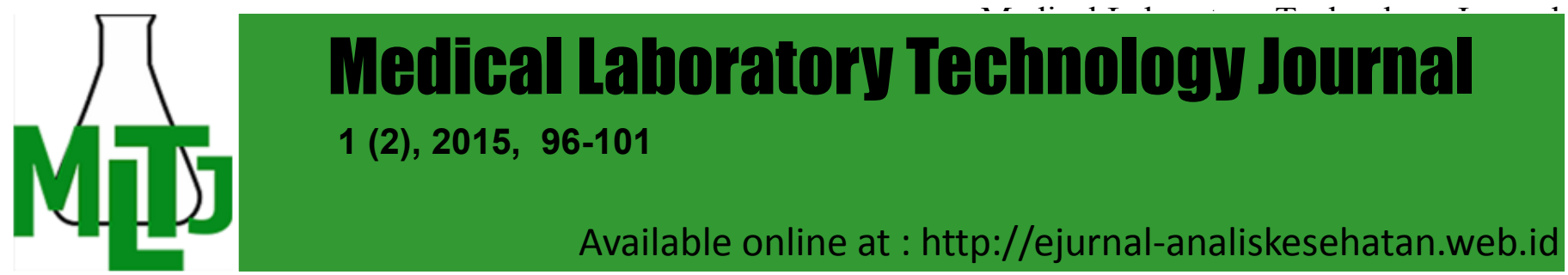

\title{
PRODUK URIKASE DARI Bacillus sp. KONTAMINAN LABORATORIUM
}

\author{
Leka Lutpiatina \\ Jurusan Analis Kesehatan Poltekkes Kemenkes Banjarmasin \\ JI Mistar Cokrokusumo 4a Banjarbaru \\ e-mail: leka.zns@gmail.com
}

\begin{abstract}
Urease is an enzyme catalyst in the reaction of oxidation of uric acid into Allantoin. Oxidation of uric acid by the enzyme has become a basic principle of measurement of uric acid levels in the human body. This research to know urikase derived from the bacterium Bacillus sp that contaminate the air Laboratory of Microbiology Department of Health Analyst Banjarmasin. The research is descriptive survey. Airborne bacteria were isolated and identified for Bacillus sp. The identification is done by examination of macroscopic, microscopic and biochemical tests subsequently performed tests using nutrient agar medium containing $0.2 \%$ of uric acid. Results of the study showed there were two isolates of Bacillus $\mathrm{sp}$ and obtained clear zone on both these isolates. Conclusions of research there are contaminants Bacillus sp. as much as $40 \%$ in the laboratory. $100 \%$ of the yield urikase Bacillus sp. Urikase advice from Bacillus $\mathrm{sp}$ can be used as an alternative reagent uric acid probes spectophotometric method.
\end{abstract}

Keywords: urikase, Bacillus sp, Laboratory of Bacterial Contamination

Abstrak: Urikase merupakan enzim katalisator dari reaksi oksidasi asam urat menjadi Allantoin. Reaksi oksidasi asam urat dengan bantuan enzim ini menjadi prinsip dasar pengukuran kadar asam urat dalam tubuh manusia. Penelitian ini untuk mengetahui urikase yang berasal dari bakteri Bacillus sp yang mengkontaminasi udara Laboratorium Mikrobiologi Jurusan Analis Kesehatan Politeknik Kesehatan Banjarmasin. Penelitian ini dilakukan dengan metode survey deskriptif. Bakteri udara diisolasi dan diidentifikasi untuk mendapatkan bakteri jenis Bacillus sp. Identifikasi dilakukan dengan pemeriksaan makroskopis, mikroskopis dan uji biokimia selanjutnya dilakukan uji dengan menggunakan media Nutrien agar yang mengandung asam urat $0.2 \%$. Hasil penelitian terdapat dua isolat yang menunjukkan Bacillus sp dan diperoleh zona bening pada kedua isolat tersebut. Kesimpulan penelitian terdapat kontaminan Bacillus sp. sebanyak $40 \%$ pada laboratorium mikrobiologi jurusan Analis Kesehatan Poltekkes kemenkes Banjarmasin. 100 \% Bacillus sp. tersebut menghasilkan urikase. Saran urikase dari Bacillus sp dapat dimanfaatkan sebagai salah satu alternatif reagen pemeriksaan asam urat metode spektofotometri.

Kata kunci : Urikase, Bacillus sp, Bakteri Kontaminan Laboratorium 


\section{PENDAHULUAN}

Urat oksidase atau urikase adalah enzim yang mengkatalisis oksidasi asam urat menjadi allantoin. Urat oksidase berfungsi untuk mencegah penumpukan asam urat dengan cara mengkatalisis oksidasi asam urat oleh molekul oksigen sehingga digunakan dalam pengukuran asam urat untuk memonitor kesehatan dan diagnosa terjadinya gagal ginjal. Urikase telah ditemukan pada mamalia, mikroba, jamur, dan tumbuhan tingkat tinggi. Salah satu mikroba yang dapat menghasilkan urikase diantaranya adalah Bacillus sp. (Iswantini dkk, 2011)

Bacillus sp. merupakan bakteri berbentuk batang dan tergolong dalam gram positif yang tumbuh pada medium yang mengandung oksigen sehingga dikenal dengan istilah aerobic sporefomers. Beberapa mikroba dari Bacillus telah menghasilkan aktivitas urikase diantaranya Bacillus subtilis TB-90 sebesar 11,4 Unit/mL dan Bacillus thermocatenulatus sebesar 1,25 Unit/mL yang dapat digunakan sebagai alternatif memperoleh enzim urikase sebagai pengganti enzim murni untuk pemeriksaan asam urat, dimana penggunaan mikroba dinilai memiliki kelebihan yaitu lebih murah, lebih toleran terhadap $\mathrm{pH}$ dan mudah diperoleh (Iswantini dkk, 2011). Selain itu Bacillus sp. sering ditemukan sebagai kontaminan di laboratorium, salah satunya di Laboratorium Mikrobiologi Analis Kesehatan Politek- nik Kesehatan Banjarmasin.

Laboratorium Mikrobiologi Jurusan Analis Kesehatan Politeknik Kesehatan Banjarmasin merupakan Laboratorium pendidikan yang biasanya digunakan untuk melakukan percobaan dan pemeriksaan mikroorganisme seperti parasit dan bakteri. Adanya metabolisme dalam tubuh makhluk hidup dan keberadaan mikroorganisme dapat menyebabkan kontaminasi, hal ini sangat berpengaruh pada ruang yang seharusnya terjaga kesterilanya misal ruang laboratorium.

Ruangan laboratorium sering ditemukan adanya mikroorganisme kontaminan. Bakteri kontaminan yang sering ditemukan diantaranya adalah Bacillus sp, Streptococcus sp, Staphylococcus, Pseudomonas dan Sarcina. Dari mikroorganisme tersebut, yang paling sering menyebabkan kontaminasi adalah Bacillus subtilis. (Pusdiknakes, 2010). Hal ini dibuktikan dengan adanya gangguan kontaminan saat praktikum seperti ditemukan bakteri lain yang terisolasi pada media. Gangguan tersebut bisa terjadi karena praktikan tidak melakukan praktikum secara aseptis.

Penelitian ini bertujuan untuk mengetahui adanya enzim urikase dari bacillus sp sebagai bakteri kontaminan Laboratorium Mikrobiologi Jurusan Analis Kesehatan Politeknik Kesehatan Banjarmasin. 


\section{BAHAN DAN METODE}

Jenis penelitian yang digunakan dalam penelitian ini adalah survey deskriptif yaitu suatu penelitian yang dilakukan dengan tujuan melihat gambaran tentang adanya urikase yang diproduksi bakteri Bacillus sp sebagai kontaminan laboratorium mikrobiologi yang ditandai dengan terbentuknya zona bening. (Saepudin, 2011 )

Bahan penelitian yang digunakan yaitu bakteri Bacillus sp. yang mengkontaminasi laboratorium mikrobiologi Jurusan Analis Kesehatan Politeknik Kesehatan Banjarmasin. Bahan penelitian diambil pada lima sudut ruang laboratorium.

Variabel dalam penelitian ini adalah urikase yang diproduksi bakteri Bacillus sp. kontaminan udara Laboratorium Mikrobiologi Jurusan Analis Kesehatan Polteknik Kesehatan Banjarmasin.

Penelitian ini dilaksanakan pada bulan September 2015 dan dilaksanakan di Laboratorium Mikrobiologi Jurusan Analis Kesehatan Politeknik Banjarmasin.

Sampel diambil dari koloni yang diduga Bacillus pada Nutrient Agar berdasarkan morfologi koloni bakteri dan dilakukan pewarnaan Gram. Koloni tersangka kemudian diinokulasikan pada media gula-gula (glukosa, laktosa, manitol, maltosal, sakarosa). Simon Citrate Agar, dan Sulfur Indol Motility (SIM) kemudian diinkubasi selama 18-24 jam pada suhu $37^{\circ} \mathrm{C}$.

Uji urikase dilakukan dengan menginokulasikan bacillus $\mathrm{sp}$ pada media Nutrient
Agar yang mengandung asam urat 0,2\%, diinkubasi selama 1 × 24 jam dan diamati adanya zona jernih yang terbentuk.

Data yang diperoleh dari pemeriksaan laboratorium dikumpulkan, diolah, disajikan, kemudian ditabulasikan dan dianalisa secara deskriptitif.

\section{HASIL DAN PEMBAHASAN}

Berdasarkan hasil pemeriksaan pada udara ruang laboratorium Mikrobiologi Jurusan Analis Kesehatan Poltekkes Kemenkes Banjarmasin didapatkan hasil yang dapat dilihat pada tabel

Tabel1 Hasil Pemeriksaan Identifikasi Bakteri Kontaminan Laboratorium Mikrobiologi Poltekkes Kemenkes Banjarmasin

\begin{tabular}{|l|l|l|}
\hline No. & KodeSampel & Hasil identifikasi \\
\hline 1 & A & Bakteri lain. \\
\hline 2 & B & Bacillus $s p$ \\
\hline 3 & C & Bakteri lain \\
\hline 4 & D & Bacillus $s p$. \\
\hline 5 & E & Bakteri lain \\
\hline
\end{tabular}

Dua isolat yang menunjukkan Bacillus sp. kemudian ditanam pada media Nutrien agar mengandung asam urat $0.2 \%$. Setelah diinkubasi pada suhu $37^{\circ} \mathrm{C}$ selama $2 \times 24$ jam diperoleh zona bening pada sampel kode B dan D. Hasil uji urikase dapat dilihat pada gambar 1. 
Gambar 1 Zone Bening pada Uji Urikase

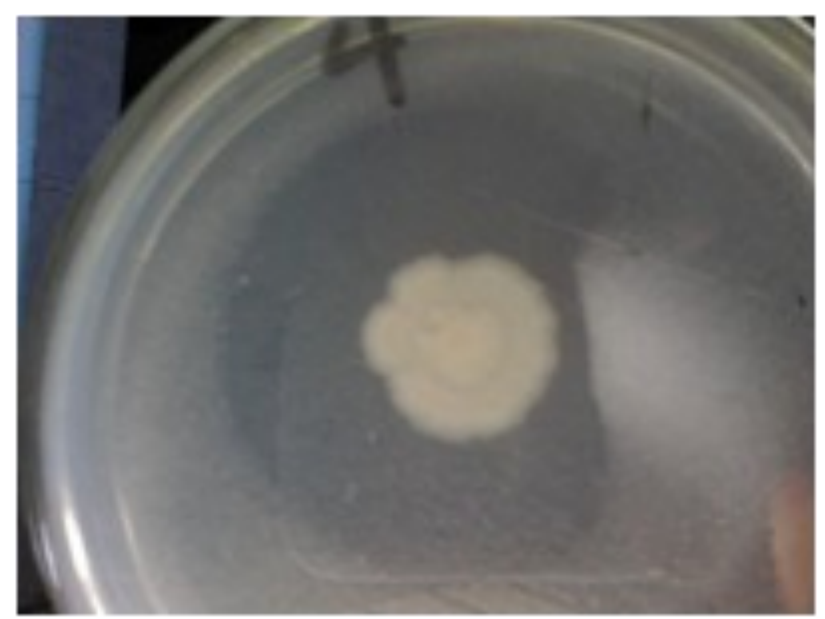

Berdasarkan penelitian terhadap bakteri kontaminan udara laboratorium mikrobiologi Jurusan Analis Kesehatan, diperoleh adanya isolat kontaminan Bacillus sp. Species bakteri ini belum dapat ditentukan dengan hasil uji yang telah dilakukan. Ciri khas yang Bacillus $s p$ yang ditemukan pada penelitian ini adalah bentuknya batang dengan ukuran yang relatif besar, susunan berantai, Gram positif, membentuk spora dan tes katalase positif.

Pusdiknakes (2010) menyebutkan kontaminasi mikroorganisme berupa bakteri pada laboratorium mikrobiologi dapat disebabkan mikroorganisme pada udara mengendap bersama debu pada berbagai permukaan. Pelepasan tidak sengaja mikroorganisme saat melakukan praktikum juga dapat menambah kontaminasi di laboratorium Mikrobiologi. Sel mikroorganisme yang berukuran kecil dan ringan mudah terhembuskan oleh aliran udara, mikroorganisme yang paling sering menyebabkan kontaminasi adalah Bacillus subtilis.
Penelitian ini juga melakukan uji urikase terhadap dua isolat bacillus sp. Aktivitas urikase bakteri dapat terlihat pada adanya zona bening di media padat yang mengandung asam urat 0,2\%. Menurut Iswantini, D. dkk., (2011) penentuan aktivitas urikase dengan cara demikian termasuk kedalam uji kualitatif karena hasil didapat secara kasar namun cepat.

Zona bening pada media padat yang mengandung asam urat $2 \%$ lebih terlihat maksimal pada hari kedua inkubasi. Zona bening isolat $B$ sebesar $3,5 \mathrm{~cm}$ sedangkan isolat $D$ sebesar $4 \mathrm{~cm}$. Ukuran zone bening pada uji ini menjadi relatif karena adanya faktor-faktor yang tidak terukur seperti banyaknya isolat yang dioleskan pada media, ukuran/besar olesan.

Penelitian Iswantini, D. dkk., (2011) menunjukkan hasil zone bening sebesar 2,5 cm untuk Bacillus subtilis dan 0,5 cm untuk Bacillus cereus, sehingga bila dibandingkan hasil penelitian ini mempunyai zone bening yang relatif lebih besar. Menurut Azab et al (2005) zona bening menunjukkan bahwa asam urat telah didegradasi oleh enzim urikase ekstraselular yang dihasilkan oleh bakteri. 
Medical Laboratory Technology Journal

Beberapa mikroba yang mampu menghasilkan urikase di antaranya Pseudomonas aeruginosa (Abdel-Fattah et al, 2005), Arthrobacter globiformis (Suzuki $\mathrm{K}$ et al.,2008), Bacillus subtilis (Pfrimer $P$ et al., 2010), and Microbacterium sp (Zhou et al., 2005). Bakteri Bacillus sp yang mengkontaminasi udara laboratorium Mikrobiologi Jurusan Analis Kesehatan Poltekkes Kemenkes Banjarmasin menghasilkan urikase yang dapat dilihat dari zone bening pada nutrien agar dengan kandungan asam urat. Hall dan Macvicar (1954), menyatakan bahwa Bacillus sp mudah diperoleh, diperbanyak dan menghasilkan amonia, sehingga diharapkan mampu menghasilkan aktivitas urikase lebih besar.

Urat Oxidase atau Urikase merupakan enzim yang digunakan pada pengukuran kadar asam urat metode spektrofotometri. Pengukuran dengan metode ini berdasarkan pada oksidasi asam urat menjadi allantoin dengan adanya enzim urikase. Mikroba sebagai alternatif pemanfaatan enzim murni sudah banyak diteliti salah satunya adalah enzim urikase pada berbagai mikroba. Urat oksidase pertama kali diisolasi dari jamur Aspergillus flavus, tetapi yang diakui dan digunakan untuk penelitian dan tujuan medis adalah Saccharomyces cerevisiae. (Gabison, 2008)

Urikase murni dalam pengukuran asam urat memiliki kelemahan karena tidak stabilnya enzim dan biayanya yang mahal, sedangkan pada urikase yang dihasilkan mikroba memiliki kelebihan yaitu lebih murah, lebih toleran terhadap $\mathrm{pH}$, dan mudah diperoleh, sehingga mengatasi kelemahan dari enzim murni tersebut digunakanlah mikroba penghasil urikase sebagai salah satu alternative (Iswantini, D. dkk., 2011).

Urikase (asam urat oksidasi) merupakan enzim yang memiliki peran penting dalam metabolisme nitrogen dan katalis spesifik untuk oksidasi asam urat dengan bantuan air dan oksigen. (Poovizh, 2014) Kurangnya urat oksidase dapat mangakibatkan peningkatan kadar asam urat dalam plasma yang kemudian akan menjadi fatal. Urat oksidase memiliki fungsi mencegah peningkatan kadar asam urat pada organisme tertentu, termasuk bakteri, ragi, jamur dan beberapa mamalia. (Colloc'h, 2006)

Urat oksidase memiliki jalur degradasi purin yang berfungsi untuk mencegah penumpukan asam urat oleh katalis oksidasi asam urat oleh molekul oksigen yang menyebabkan produksi 5-hydroxyisourate dan hidrogen peroksida. Meskipun enzim ini ditemukan di banyak organisme, tetapi jumlah yang tertinggi terdapat pada kera dan manusia. (Gabison, 2008)

\section{KESIMPULAN}

Terdapat kontaminan Bacillus sp. sebanyak $40 \%$ pada laboratorium mikrobiologi jurusan Analis Kesehatan Poltekkes kemenkes Banjarmasin.

100 \% Bacillus sp. kontaminan laboratorium mikrobiologi jurusan Analis Kesehatan Poltekkes kemenkes Banjarmasin menghasilkan urikase. 


\section{DAFTAR PUSTAKA}

Abdel-Fattah YR, Saeed HM, Gohar YM, ElBaz MA. Improved production of Pseudomonas aeruginosa uricase by optimization of process parameters through statistical experimental designs. Process Biochem 2005 ;40: 1707-14

Azab E.A., Ali M.M., Farred M.F. 2005. Studies on uricase induction in certain bacteria. Egyptian Journal of Biology 7:44-54

Colloc'h, N. dkk. Crystal structure of the protein drug urate oxidase-inhibitor complex at 2.05 A resolution. Nat Struct Biol. 1997 November 4(11), (http://protopedia.org/ wiki/index.php/Urate Oxidase, diakses 13 Juli 2015).

Gabison, L. dkk. Structural analysis of urate oxidase in complex with its natural substrate inhibited by cyanide: mechanistic implications. BMC Struct Biol. 2008 Jul 20, (http://protopedia.org/wiki/index.php/ Urate_Oxidase, diakses 13 Juli 2015).

Iswantini, D., Nurhidayat, N., Trivadila, Nurjayati, A. 2011. Penentuan Kinetika Urikase dari Sel Bacillus subtilis, $B$. megaterium, dan B. cereus. Jurnal IImu Pertanian Indonesia, (Online), Agustus 2011, (http://journal.ipb.ac.id/index.php/ JIPI/article/viewFile/6607/5134, diakses 12 Juli 2015).

Pfrimer P, de Moraes LM, Galdino AS, Salles LP, Reis VC, De Marco JL, Prates MV, Bloch C Jr,Torres FA. Cloning, Purification, and Partial Characterization of $\mathrm{Ba}$ - cillus subtilis Urate Oxidase Expressed in Escherichia coli, J Biomed Biotechnol 2010; 674908.

Poovizh, T., Gajalakshmi, P., \&Jayalakshmi, S. 2014. Production of Uricase a Therapeutic Enzyme from Pseudomonas puttida Isolated from Poultry Waste. International Journal of Advance Research, (Online), Volume 2, No. 1, (http:// www.journalijar.com, diakses12 Juli 2015).

Pusat Pendidikan Tenaga Kesehatan Badan PPSDM Kesehatan. 2010. Standar Laboratorium Keperawatan Pendidikan Tenaga Kesehatan, (Online), diakses 13 juli 2015

Suzuki K, Sakasegawa S, Misaki H, Sugiyama M. Molecular Cloning and Expression of Uricase Gene from Arthrobacter globiformis in Escherichia coli and Characterization of the Gene Product. $J$ Biosci Bioeng 2004; 98: 153-8.

Zhou X, Ma X, Sun G, Li X, Guo K. Isolation of a thermostable uricase-producing bacterium and study on its enzyme production conditions. Process Biochem 2005; 40: 3749-53. 